\title{
Health effects of brick kiln operations: A study on largest brick kiln cluster in Bangladesh
}

\author{
Tanmoy Roy Tusher ${ }^{1}$, Zisan Ashraf ${ }^{2}$, Shilpi Akter ${ }^{3}$
}

${ }^{1}$ Assistant Professor; ${ }^{2,3}$ Research Masters Student; Department of Environmental Science and Resource Management, Mawlana Bhashani Science and Technology University, Tangail-1902, Bangladesh.

\begin{abstract}
Brick manufacturing industry is considered as one of the fastest-growing industrial sectors posing serious health hazards in most South East Asian countries like Bangladesh. A major portion of brick kilns in Bangladesh are located in and around the Dhaka, one of the world's most densely populated cities, where the health effects of these brick kilns are obvious but yet not completely known. The study was thus performed based on a structured questionnaire survey to assess the health effects of brick kiln operations on kiln workers and local inhabitants at Baghiya of Konabari union in Gazipur near Dhaka of Bangladesh. A total of 100 randomly selected respondents (70 brick kiln workers and 30 local inhabitants) were surveyed. The results of the survey revealed that wood and coal are mostly used fuel for brick production in the study area. The respondents were suffering from skin disease $(28 \%)$, headache $(20 \%)$, eye irritation $(10 \%)$, lung disease $(8 \%)$, and respiratory diseases such as, asthma $(20 \%)$, bronchitis $(10 \%)$ and others $(6 \%)$ problems, while skin diseases, asthma and other lung diseases were prevalent in workers, and eye irritation, headache and bronchitis were in inhabitants. Inhabitants $(36 \%)$ who were living in surrounding areas of brick kilns for more than 20 years and workers (40\%) who were residing for less than 5 years were suffering most from various diseases. Health education or awareness programs need to be organized since $77.1 \%$ and $63.3 \%$ of the workers and inhabitants, respectively, were never participated in any health education or awareness programs, and eco -friendly brick kilns should be installed maintaining the existing rules and regulations for minimizing the impacts of brick kiln operation induced air pollution in this respect.
\end{abstract}

Keywords: Brick kiln, Health problems, Kiln workers, Inhabitants, Bangladesh.

\section{Introduction}

Brick kiln operations induced air pollution is one of the severe problems worlds facing today, especially for

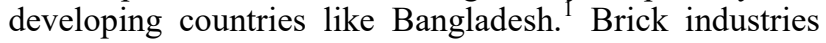
are growing rapidly in Bangladesh, India, and Nepal where more than 108,000 brick kilns are in operation and, thus, air pollution increases along with it; resulting in degradation of ecological condition, acute and chronic effects on human health and also property damages. ${ }^{2-5}$ It is most dangerous among all type of pollutions because man need fresh air for their normal metabolic pathways. ${ }^{6}$ Most of the brick kilns are poorly designed, which cause incomplete combustion of coals mostly used fuel for brick production. ${ }^{5}$ Incomplete combustion of this coal, sometimes rubber tires, produces carbon monoxide (CO), sulfur dioxide $\left(\mathrm{SO}_{2}\right)$, nitrogen oxides $\left(\mathrm{NO}_{\mathrm{x}}\right)$, ozone $\left(\mathrm{O}_{3}\right)$, hydrocarbons (HC), particulate matter (PM), fluoride compounds, and small amount of carcinogenic dioxins. ${ }^{7-9}$ Exposure to these air pollutants can overload or break down natural defense mechanisms in the body, causing or contributing to respiratory diseases such as lung cancer, asthma, chronic bronchitis, and emphysema, which at high enough concentrations can even be fatal. ${ }^{8,}$

A health survey conducted by Joshi \& Dudani ${ }^{9}$ in Nepal clearly showed that people who are living near brick kilns are more likely to suffer from illnesses caused by kilns pollution, comparing those who are living in areas without the kilns. School children nearby brick kilns were had the worse condition of health and they were suffered for higher prevalence of upper respiratory tract infections like

\section{Practice Points}

- In South East Asian countries, brick manufacturing industry is one of the fastest-growing industries posing serious health problems which are yet not completely known.

- The results of the survey revealed that wood and coal are mostly used fuel for brick production in the study area.

- The study reveals that skin diseases, asthma and other lung diseases were prevalent in workers, while eye irritation, headache and bronchitis were in inhabitants.

- Inhabitants living around kiln areas for $>20$ years and workers working there for $<5$ years were suffering most from health problems.

- The study recommends that eco-friendly brick kiln should be established and workers should use mask during working hours. .

pharyngitis and tonsillitis. ${ }^{9}$ In Bangladesh, it is reported that brick kilns produced PM 2.5 (particulate matter) which is considered more harmful to human health, because it has the capacity to travel deeper into the respiratory system and cause premature mortality and respiratory ailments. ${ }^{10}$ From these PM, mainly both elder people and children are suffered more than

Correspondence: Tanmoy Roy Tusher, Assistant Professor, Department of Environmental Science and Resource Management, Mawlana Bhashani Science and Technology University, Tangail-1902, Bangladesh. E-mail: tusrroy@yahoo.com.

South East Asia Journal of Public Health 2018;8(1):32-36. (C) 2018 Tusher et al. publisher and licensee Public Health Foundation Bangladesh. This is an Open Access article which permits unrestricted non-commercial use, provided the original work is properly cited. DOI: https://doi.org/10.3329/seajph.v8i1.42270 
any ages because on these stages of life our disease prevention mechanisms become weaker. ${ }^{11}$ Under these circumstances, the present study was conducted to investigate the effects of brick kiln operations on the public (brick kiln workers and local inhabitants) health at Baghiya of Konabari union in Gazipur district, Bangladesh

\section{Materials and methods}

Study area

The study was conducted at the Baghiya of Konabari union in Gazipur Sadar Upazila which was approximately at the latitude $24^{\circ} 01^{\prime} 40.00^{\prime \prime} \mathrm{N}$ and longitude $90^{\circ} 20^{\prime} 05.05^{\prime \prime} \mathrm{E}$. The elevation of the study area was approximately $10 \mathrm{~m}^{12}$ The study area is a part of the largest brick kiln cluster of Bangladesh located in Gazipur where approximately 320 kilns are in operation, each consisting of 200-300 daily wage workers per kiln. ${ }^{13,14}$

\section{Data collection}

With the help of random sampling, 100 respondents including 70 brick kiln workers and 30 inhabitants were surveyed from the study area during the period from February to May 2015. A structured questionnaire was developed by the authors, which was composed of 16 questions covering with both the closed and open-ended questions to gain the maximum possible results. Because it is believed that closed-ended questions probably limit the responses to the topics. ${ }^{15}$ The questions were asked sequentially and the replies were noted down carefully. Approvals were obtained from brick kiln owners and informed consent was sought from the respondents.

\section{Data analysis}

The data were analyzed by using Statistical Package for Social Science (IBM SPSS Statistics 20.0) and Microsoft Office Excel 2010.

\section{Results}

The study found that $34 \%$ respondents were belonging to the age group of 21-30 years, while 22,24 , and $20 \%$ of the respondents were in the age group of below 20 years, 31-40 years, and above 40 years, respectively. Among the respondents $(70 \%$ workers and 30\% inhabitants), $64 \%$ were male and $36 \%$ were female, where $38 \%$ of the respondents were illiterate and $10 \%$ were graduate (Table 1). The study revealed that the highest proportion of the respondents $(48.6 \%)$ who were workers $(\mathrm{N}=70)$ and were living in or around the study area for less than 5 years, while only $7.1 \%$ of them are living for more than 20 years in the area. In case of inhabitants $(\mathrm{N}=30), 33.3 \%$ of the respondents are living in or around the study area for more than 20 years (Table 1). The results of the survey found that about $50 \%$ of the workers identified wood and coal as the fuel used for brick production in their kilns, while $15.7 \%$ used wood, $20 \%$ used coal and $14.3 \%$ used others types of fuels for brick production in the study area.

The study revealed that the respondents were higher prevalence of skin disease $(28 \%)$, asthma $(20 \%)$, headache $(18 \%)$, eye irritation $(10 \%)$, bronchitis $(10 \%)$, other lung disease $(8 \%)$ and others $(6 \%)$ diseases due to brick kiln operations (Fig. 1). Among the respondents, workers were badly suffering from skin diseases (32\%), asthma (22\%) and other lung diseases (10\%) than the inhabitants due to working continuously at the brick kiln periphery. On the other hand, inhabitants living here for many years were influenced by surrounding adverse environmental conditions and were suffering much from eye irritation (12\%), headache $(20 \%)$, bronchitis $(12 \%)$ and others diseases $(8 \%)$ than the workers (Fig. 2). That implies that workers were suffering much from skin disease, asthma and lung disease than the inhabitants though headache, eye irritation and bronchitis were prevalent in inhabitants (Fig. 2). The study also showed that $36 \%$ were affected by various diseases because they are living the surrounding areas of brick kilns above 20 years (Fig. 3). On the other hand, in the case of rest 70 respondents (workers), 40\% were affected by various diseases because they were working continuously in the brick field below 5 years for their livelihood while $8 \%$ of the workers are less affected who live here above 20 years, because they often migrate from this place to another place for their existence (Fig. 4).

Among the respondents, only $22.9 \%(\mathrm{~N}=16)$ and $36.7 \%$ $(\mathrm{N}=11)$ of the workers and inhabitants, respectively, participated in different health education and awareness programs organized by several Governmental organizations or Non-Governmental organizations (NGOs), whereas most of the respondents, $77.1 \%$ and $63.3 \%$ of

Table 1: Socio-demographic profile of the respondents

\begin{tabular}{|c|c|}
\hline Variables & Respondents (\%) \\
\hline \multicolumn{2}{|l|}{ Age } \\
\hline Below 20 years & $22(22.0 \%)$ \\
\hline $21-30$ years & $34(33.0 \%)$ \\
\hline $31-40$ years & $24(24.0 \%)$ \\
\hline Above 40 years & $20(20.0 \%)$ \\
\hline \multicolumn{2}{|l|}{ Gender } \\
\hline Male & $64(64.0 \%)$ \\
\hline Female & $36(36.0 \%)$ \\
\hline \multicolumn{2}{|c|}{ Educational Qualifications } \\
\hline Primary & $18(18.0 \%)$ \\
\hline Secondary & $20(20.0 \%)$ \\
\hline Higher secondary & $14(14.0 \%)$ \\
\hline Graduate & $10(10.0 \%)$ \\
\hline Illiterate & $38(38.0 \%)$ \\
\hline \multicolumn{2}{|l|}{ Occupation } \\
\hline Workers & $70(70.0 \%)$ \\
\hline Inhabitants & $30(30.0 \%)$ \\
\hline \multicolumn{2}{|c|}{ Workers $(N=70):$ Working duration } \\
\hline Below 5 years & $34(48.6 \%)$ \\
\hline $5-10$ years & $20(28.6 \%)$ \\
\hline $10-20$ years & $11(15.7 \%)$ \\
\hline Above 20 years & $5(7.1 \%)$ \\
\hline \multicolumn{2}{|c|}{ Inhabitants $(N=30):$ Residence duration } \\
\hline Below 5 years & $5(16.7 \%)$ \\
\hline $5-10$ years & $6(20.0 \%)$ \\
\hline $10-20$ years & $9(30.0 \%)$ \\
\hline Above 20 years & $10(33.3 \%)$ \\
\hline \multicolumn{2}{|c|}{ Workers' participation: Environmental Programs } \\
\hline Yes & $16(22.9 \%)$ \\
\hline No & $54(77.1 \%)$ \\
\hline \multicolumn{2}{|c|}{ Inhabitants' participation: Environmental Programs } \\
\hline Yes & $11(36.7 \%)$ \\
\hline No & $19(63.3 \%)$ \\
\hline \multicolumn{2}{|c|}{ Use of masks during working hours } \\
\hline Yes & $11(15.7 \%)$ \\
\hline No & $59(84.3 \%)$ \\
\hline
\end{tabular}


the workers and inhabitants, respectively, were never participated in any health education or awareness raising programs (Table 1). Health and safety measures taken by the workers were also determined through questionnaire survey. Among the respondents, $15.7 \%$ of the workers stated that they use mask and also concerned about the health impacts of brick kiln emissions induced air pollution. On the other hand, $84.3 \%$ of the workers stated that they never use mask during working period as they not concerned about the health impacts of brick kiln emissions because training program from brick kiln authority were not provided to them (Table $1)$.

\section{Discussion}

Health problems are one of the important determinants which depicted the relationship between respondent groups and their interactions with surrounding environ- mental conditions. Brick kiln emission significantly degrades the surrounding air quality and poses serious health problems to inhabitants in the locality. Brick kilns industries typically use woods, recycled motor oils, coals, fuel oils, diesels, tires, trashes, and plastics for fuel. ${ }^{5}$ Combustion of these fuels in brick kilns produce air pollutants like $\mathrm{CO}_{\mathrm{X}}, \mathrm{SO}_{\mathrm{X}}, \mathrm{NO}_{\mathrm{X}}$ and suspended particulate matter (SPM). ${ }^{16}$ All of these pollutants play important role in the development of respiratory diseases, such as pneumoconiosis and silicosis, and irritation of skin and eyes in nearby population when inhaled to these pollutants. ${ }^{5,16,17}$ Incomplete combustion of coal could also cause undesirable health effects on central nervous system and eventually resulted in symptoms of headache, nausea, exertion and shortness of breath. ${ }^{16,18,19}$ The suspension of particulate matter in air can last from a few minutes to many hours and can travel from $<1 \mathrm{~km}$ to $10 \mathrm{~km} .^{20}$ Thus, the people living far away from the brick kiln

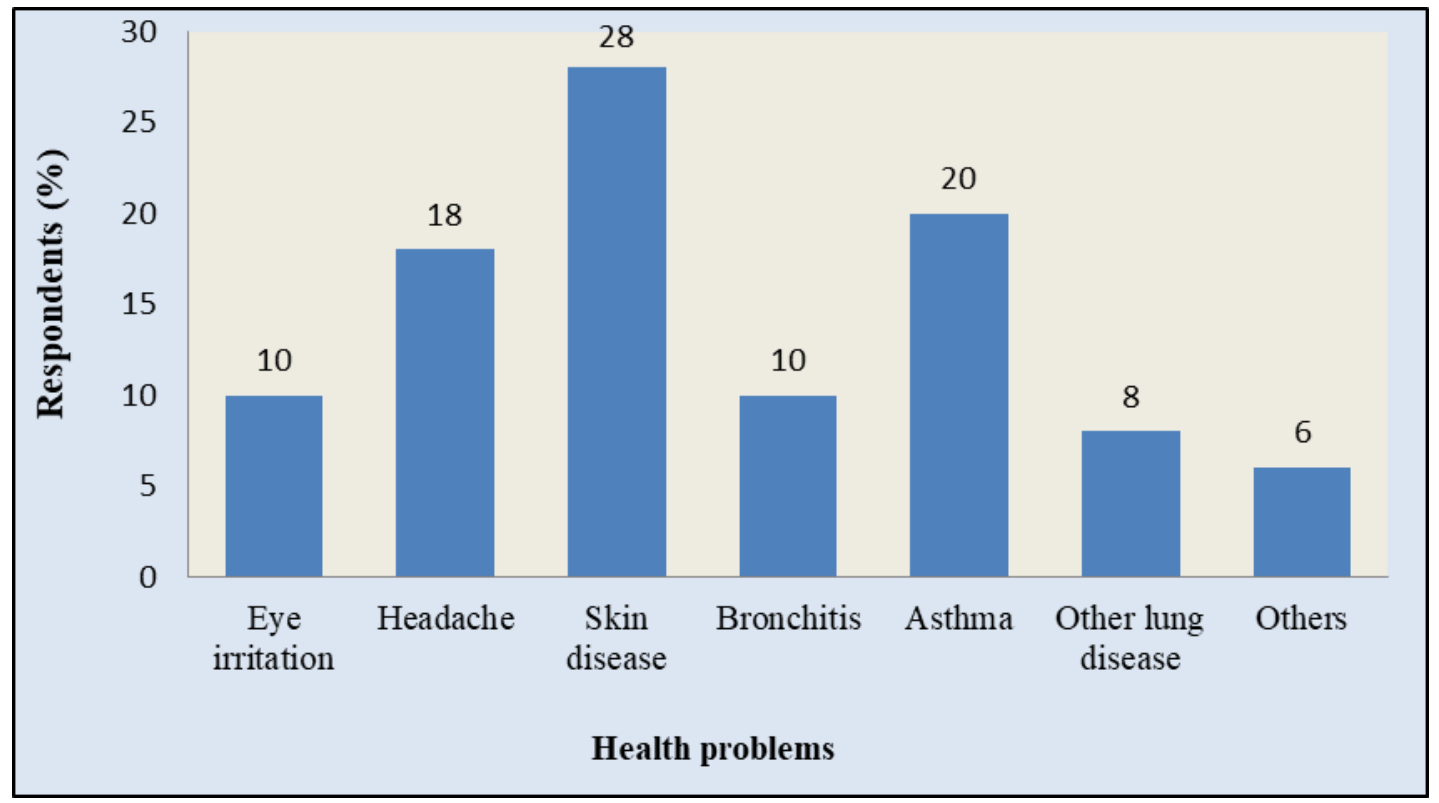

Figure 1: Health problems of the respondents

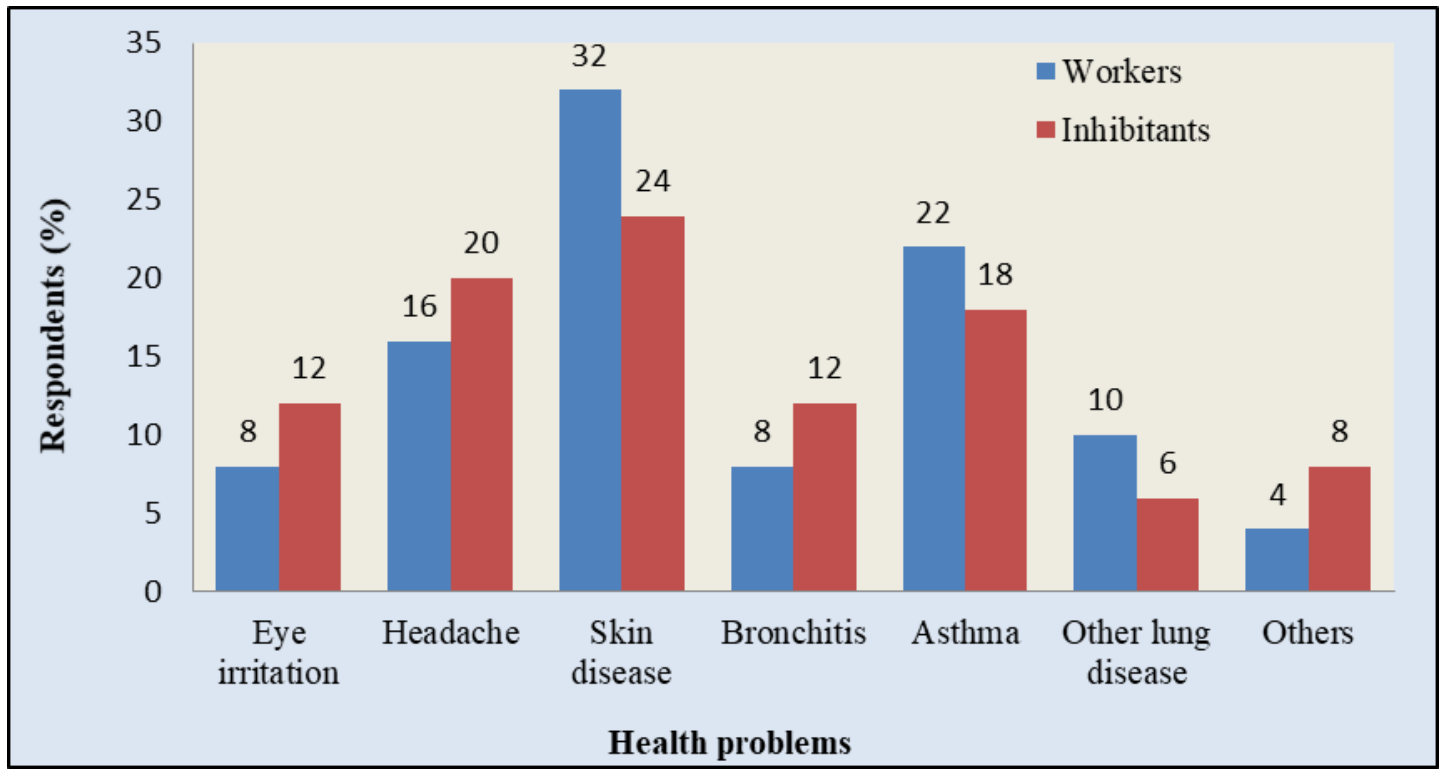

Figure 2: Relationship between health problems and respondents groups. 


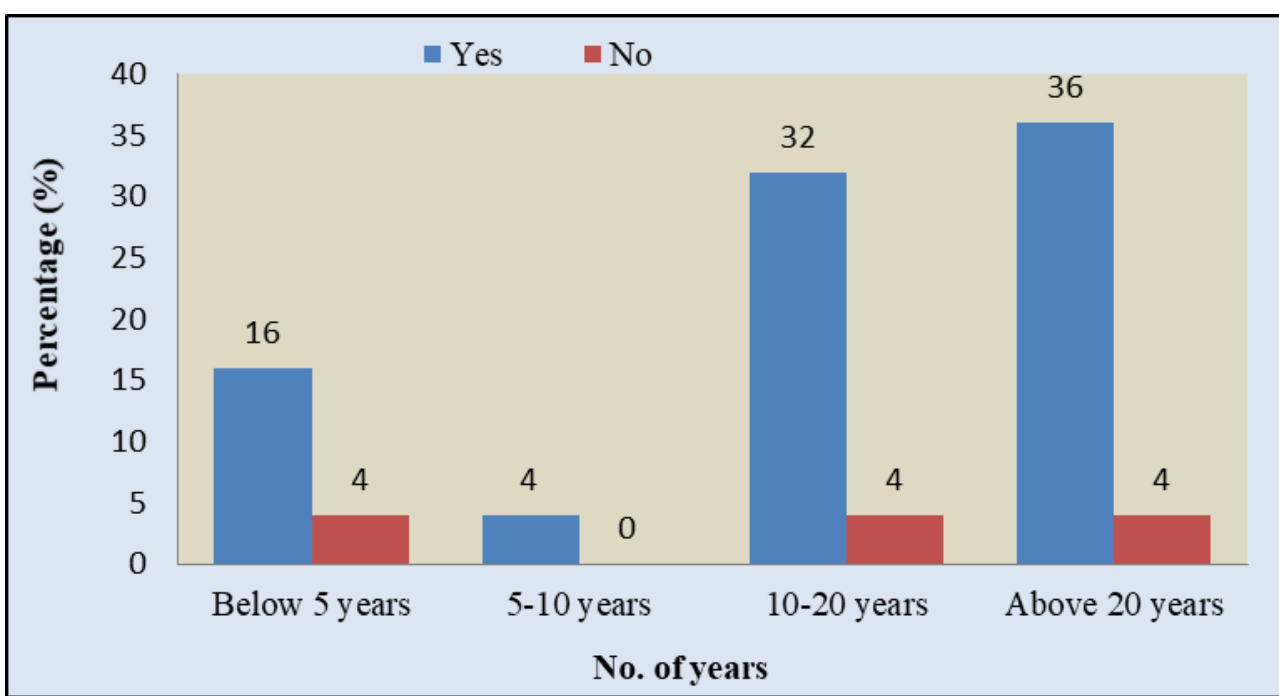

Figure 3: Inhabitants' suffering from different health problems as a function of residence duration in the study area

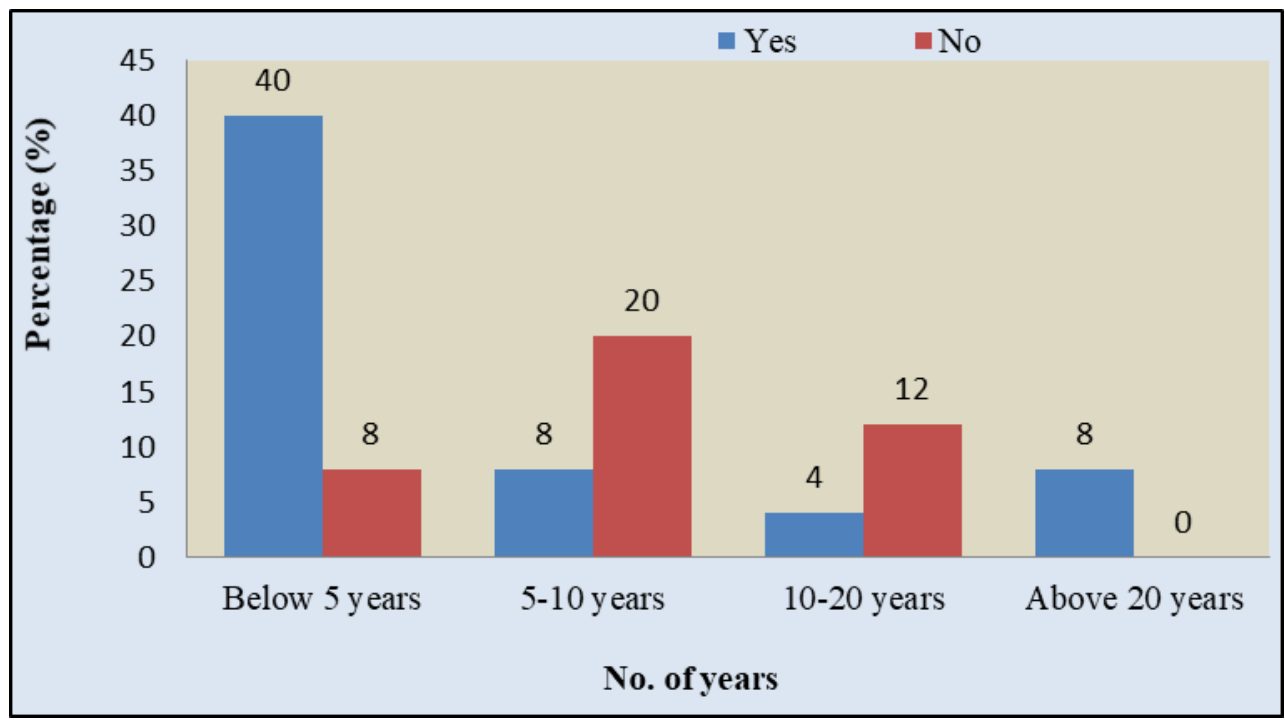

Figure 4: Workers' suffering from different health problems as a function of working duration in the study area

clusters are also suffered from such health problems. However, Joshi and Dudani observed that peoples living near brick kilns are more likely to suffer from illnesses, comparing those who are living in areas without the kilns. ${ }^{9}$ Emissions from brick kilns can also cause headache, nausea, and other respiratory diseases. ${ }^{11,21,22}$ These pollutants can also inhibit the mental and physical growth of children. ${ }^{23}$ School children near to the brick kiln industries had the worst health status and suffered from upper respiratory infections like pharyngitis and tonsillitis.

\section{Limitation of the study}

The study was conducted based on questionnaire survey which may sometimes inadequate to bring the exact results about the health problems associated with brick kiln operation and subsequent emission.

\section{Conclusion}

The study revealed that workers are suffering much from skin disease, asthma and others lung disease while headache, eye irritation and bronchitis were prevalent in in- habitants. Thus, it can be stated with one voice that the status of public health, especially in vicinity of brick field areas, is under threat in the study area. However, in-depth physiological study is needed to be carried out for the better assessment of the effects of brick kiln emission. In such condition, ecofriendly brick kiln should be established and workers should be trained up and should use mask during working period. In the meantime, training programs for kiln workers and local inhabitants on health and safety measures should be organized regularly in order to raise environmental awareness as well as to maintain workers health and safety.

\section{Competing interest}

The authors declared that there is no conflict of interest.

\section{Funding}

No funding received for this study. 


\section{References}

1. Ahmed S, Hossain I. Applicability of air pollution modeling in a cluster of brickfields in Bangladesh. Chem Eng Res Bull 2008; 12: 28-34.

2. Fatima, I. Impact of brick kiln emissions on the ambient air quality and vegetation: A case study of district Budgam. [MPhil. Dissertation] Department of Environmental Science, University of Kashmir, India 2011.

3. Tripathi AK, Gautam M. Biochemical parameters of plants as indicators of air pollution. $J E n-$ viron Biol 2007; 28(1): 127-32.

4. Kampa M, Castanas E. Human health effects of air pollution. Environ Pollut 2008; 151(2): 362-7.

5. Pariyar SK, Das T, Ferdous T. Environment and health impact for brick kilns in Kathmandu Valley. Int J Sci Tech Res 2013; 2(5): 184-7.

6. Azim MR, Mahmood Q, Ahmad SS. Risk evaluation of brick kiln smoke to Kidney Bean (Phaseolus vulgaris). Pak J Bot 2013; 45(4): 1403-6.

7. 7. Skinder BM, Pandit AK, Sheikh AQ, Ganai BA. Brick kiln: Causes of atmospheric pollution. J Pollut Effect Control 2014; 2(2): 2-7.

8. Ahmmed KMT, Begum DA. Air pollution aspects of Dhaka city. Proceedings of International Conference on Environmental Aspects of Bangladesh (ICEAB10), Japan. 2010; 129p.

9. Joshi SK, Dudani I. Environmental health effects of brick kilns in Katmandu valley. Katmandu Uni Med J 2008; 6(1):3-11.

10. Guttikunda S. Impact analysis of brick kilns on the air quality in Dhaka, Bangladesh. SIM working paper series 21-2009. [Retrieved from: http:// indiaenvironmentportal.org.in/files/Dhaka-AQBrick\%20Kilns.pdf]

11. Environmental Protection Agency. Health and environmental effects of Particulate Matter (PM). United States Environmental Protection Agency, 2015. [Retrieved from: https://www.epa.gov/pmpollution/health-and-environmental-effectsparticulate-matter-pm (accessed June 2018)

12. Banglapedia. National Encyclopedia of Bangladesh, Dhaka: Asiatic Society of Bangladesh, 2013. http://en.banglapedia.org/index.php? title=Gazipur Sadar Upazila (accessed June 2018)
13. Global Environment Facility-United National Development Programme. Impact of brick kiln pollution on Dhaka city. GEF-UNDP study, $2006 . \quad$ http://centers.iub.edu.bd/chpd/ Pres_Sem_Ijaz\%20Hossain_Aprl\%2017-08.pdf (accessed June 2018)

14. World Bank. Introducing energy-efficient clean technologies in the brick sector of Bangladesh, Report No. 60155-BD, Washington DC: Environment, Climate Change and Water Resource Unit, World Bank, 2010.

15. Fraenkel JR, Wallen NE. How to design and evaluate research in education. New York: McGraw-Hill Publishers Ltd., 1996.

16. Zuskin EJ, Musajbegovic EN, Schachter J, Kern J, Docko-Jelinic, Cvar JG. Respiratory findings in workers employed in the brick-manufacturing industry. J Occup Environ Med 1998; 40(9): 814 -20 .

17. Khan R, Vyas H. A study of impact of brick industries on environment and human health in Ujjain city (India). J Environ Res Dev 2008; 2: 421-5.

18. Seinfeld JH, Pandis SN. Atmospheric chemistry and physics: Pollution to Climate Change. New York: John Wiley and Sons, Inc., 1998.

19. Maynard RL, Waller R. Carbon monoxide. In: Holgate ST, Samet JM, Koren HS and Maynard RL (eds.). Air pollution and health. Academies Press: Harcourt Brace and Company, Publishers, 1999.

20. Reddy YBR, Reddy SM, Reddy CBS. Determination of respirable suspended particulate matter, Non-respirable suspended particulate matter and total suspended particulate matter in Piduguralla industrial area, India. Int Res J Environ Sci 2015; $4: 45-51$

21. Environment Improvement Programme. Assessment of the applicability of Indian cleaner process technology for small scale brick industries of Kathmandu. Kathmandu: Metropolitan Environment Improvement Programme, 1995.

22. Dara SS. A textbook of environmental chemistry and pollution control. New Delhi: S. Chand and Company Ltd. Ram Nagar, 2007.

23. Hossain M, Abdullah AM. Securing the environment: Potentiality of green brick in Bangladesh. BUP J 2012; 1(1): 29-39. 